Historia Slavorum Occidentis

2021, nr 4 (31)

ISSN 2084-1213

DOI: $10.15804 /$ hso210403

Wojciech Sajkowski (Poznań)

ORCID: 0000-0002-8585-4149

\title{
Image of the Slavs inhabiting the Habsburg Monarchy in Voyage en Autriche by Marcel de Serres
}

Keywords: Slavdom, Napoleonic era, Habsburg Monarchy, stereotypes

Słowa kluczowe: Słowiańszczyzna, epoka napoleońska, monarchia habsburska, stereotypy

\begin{abstract}
This paper focuses on the depiction of the Slavs in a work by a French naturalist Marcel de Serres, published in 1814 and entitled Voyage en Autriche. This work is an example of the analysis including a very detailed reflection on Slavdom, made in time of the increasing political engagement of Napoleonic France in Southeastern and Central Europe. The author of the work deliberated on the character of the Slavs and their presumed national unity, simultaneously searching for the ways to explain very apparent differences between various Slavic populations. According to Marcel de Serres the Slavs of the Habsburg Monarchy formed two geographical branches (western and oriental) and were divided into seven principal races, and twenty-seven "secondary branches". Voyage en Autriche depicted regularities, which were supposed to characterize all of the Slavs, but Marcel de Serres devoted much attention to some details which were considered as exotic and later were described by the writers of the Romantic period fascinated with the Slavic culture.
\end{abstract}

\section{Introduction}

The second half of the $18^{\text {th }}$ and the beginning of the $19^{\text {th }}$ century was a crucial moment in shaping the Western European image of the Slavs. Firstly, the understanding of the term "Slavs" evolved as a new terminology, which described human societies, 
emerged in the times of the Enlightenment. ${ }^{1}$ Secondly, this period was an important time in shaping the perception of the European civilizational geography, as the division between the European North and South was gradually replaced by the division between the East and the West. ${ }^{2}$ This process coincided with the emergence of the Eastern Question: as the Ottoman Turkey was weakening, its European possessions became the territory of the rivalry of Habsburg Monarchy, France and Russia. ${ }^{3}$ This political process stimulated the discovery of the different societies of Southeastern Europe, including the South Slavs. ${ }^{4}$

This paper concentrates on Voyage en Autriche ou essai statistique et geographique sur cet empire by Marcel de Serres, one of the studies which includes this new reflection on Slavdom made in the perspective of the increasing political engagement of the European powers (in this case: Napoleonic France) in Southeastern Europe. ${ }^{5}$ The author of the abovementioned work was a famous geologist and paleontologist which was sent by French authorities as a civil official to Habsburg Monarchy in 1809. ${ }^{6}$ This travel resulted in a four-volume study on its geography, natural resources, as well as its complex multi-ethnic population and history of particular societies which were forming it. In fact, his work, which was described as "travelogue" was rather a sort of memoir, similar to some military reports made by French officers

1 J. Fine, When ethnicity did not matter in the Balkans: A Study of identity in pre-nationalist Croatia, Dalmatia and Slavonia in the medieval and early-modern periods, Ann Arbor 2006, p. 272; W. Sajkowski, French image of the inhabitants of the Illyrian Provinces and the emergence of South Slavic nationalisms, Balcanica Posnaniensia. Acta et studia 27 (2020), pp. 69-80.

2 P. Hazard, La crise de la conscience européenne, Paris 1995, pp. 48-71; L. Wolff, Inventing Eastern Europe: the map of civilization on the mind of the Enlightenment, Stanford 1994, pp. 144$-194$.

3 H. Kohn, Pan-Slavism: Its History and Ideology, New York 1960, p. XIII; O. Varlan, La France, la Russie et les Balkans. Les plans de partage de l'empire ottoman (1808), [in:] Les Provinces illyriennes dans l'Europe napoléonienne (1809-1813), éd. J.O. Boudon, Paris 2015, pp. 29-42; R. Raspopović, La France et la Russie dans les projets de redistribution du Sud-Est de l'Europe au début du XIXe siècle, [in:] Les Provinces illyriennes, pp. 77-85; S. Šoja, La saga napoléonienne en Bosnie au début du XIXe siècle, [in:] Les Provinces illyriennes, pp. 87-98.

4 M. Todorova, Imaging Balkans, Oxford 2009, pp. 89-115.

5 M. de Serres, Voyage en Autriche ou essai statistique et géographique sur cet empire (etc.), Paris 1814.

6 J.J. Langendorf, Les voyageurs de l'Empire: l'Autriche-Hongrie à la découverte du monde, 1318-1918, Paris 1966, p. 9. 
and civil officials of that time, e.g., Aleksander Sapieha's "travel to Slavic countries", Lujo Matutinović's description of Dalmatia ${ }^{8}$ or many other documents made for the internal purpose of French intelligence. ${ }^{9}$ Voyage en Autriche was also made primarily for the internal use of French administration and was published in 1814, already after the fall of the Napoleonic reign in Illyrian Provinces, ${ }^{10}$ when projects of French economic and political expansion in Southeastern Europe were abandoned.

The work of Marcel de Serres seems to be overlooked by the researchers who were interested in the evolution of the Western European image of Slavdom. The research studies focused on such persons as Claude-Charles de Peyssonnel, Alberto Fortis, Charles Nodier or Prosper le Merimée who delivered specific studies on the Slavs, ${ }^{11}$ while Marcel de Serres delivered a general work on the Habsburg Monarchy. However, Voyage en Autriche favorized the subject of Slavdom. In the introduction to this work Marcel de Serres clearly indicated that this problem will be one of the main issues deliberated in his work: "In the travels which I have made in the various regions of Austria, I have taken a great interest in knowing the various races which compose the population, and among these the Slavic nation especially attracted my attention." 12 The acknowledgement of the importance of the Slavic question, justified mainly by the demographic issues ("the Slavic nation is the most numerous of all those inhabiting Europe"13), was reflected in the content of the work: a huge part

7 A. Sapieha, Podróże w krajach słowiańskich odbywane, red. T. Jabłoński, Novi Sad-Wrocław 1983.

8 L. Matutinović, Ogled o Ilirskim provincijama i Crnoj Gori, transl. J. Milinković, Zagreb 2009.

9 W. Sajkowski, French image of the peoples inhabiting Illyrian Provinces, Warszawa-Bellerive-sur-Allier 2018, p. 17.

10 Part of the $1^{\text {st }}$ French Empire which existed in the years 1809-1813 with capital in Ljubljana. The population of the Illyrian Provinces consisted of Croats (Croatia, Dalmatia, Istria), Slovenes (Krajina, Carinthia, Istria, Gorizia), Serbs (Croatia and Dalmatia), Italians (Gorizia, Istria, Dalmatia) and Germans (Tyrol, Carinthia).

11 V. Yovanovitch, La guzla de Prosper Mérimée, étude d'histoire romantique, Paris 1911; R. Maixner, Charles Nodier en Illyrie, Revue des études slaves 3/4 (1924), pp. 252-263; I. Bešker, Morlacchi nella letteratura europea, Roma 2007.

12 “Dans les voyages que j'ai faits dans les divers états de l'Autriche, j'ai mis un grand intérêt à connaitre les diverses races qui en composent la population, et parmi celles-ci la nation esclavonne devait surtout attirer mes regards. Le grand nombre de Slawes ou d'Esclavons qui habitent l'Autriche appelle déjà l'attention du voyageur" - M. de Serres, Voyage en Autriche, vol. 1, p. 321.

13 "La nation esclavonne est la plus nombreuse de toutes celles qui habitent l'Europe" - ibidem, vol. 4., p 321. 
of the fourth volume of the work was devoted solely to the Slavs, while the specific information of different Slavic groups (e.g. Croats or Czechs) appear also in other volumes of the work.

\section{The depiction of the Slavs as one nation}

De Serre's work delivers one of the first attempts of the general classification of the Slavic peoples using the terminology which was created for the purpose of the anthropology of the Enlightenment. The most important term is of course that of "the nation" which is used to describe the entirety of the Slavs. At the beginning of the $19^{\text {th }}$ century this term could be used in three ways, which were often complementary. The first definition of nation, which was of pre-Enlightenment origin, was explained e.g. in Encyclopedia by Diderot and d'Alembert as "a considerable number of people, who live on a specified portion of land enclosed within particular borders, and who obey the same government". ${ }^{14}$ This definition, which assumed only the bonds of being governed by the same ruler and inhabiting certain geographical space was completed by the remark that every nation has its own character: "the genre of the proverb tells us so: carefree as a Frenchman, jealous as an Italian, serious as a Spaniard, wicked as an Englishman, proud as a Scotsman, drunk as a German, lazy as an Irishman, duplicitous as a Greek, etc.. ${ }^{15}$ This "proverbial" connotation did not disappear in $18^{\text {th }}$ century, but the Enlightenment added a new one, which became especially important during the French revolution: the nation became a community of citizens which had equal rights and duties specified in the social contract. The third, and the last definition of the nation is usually associated with Herder's concept of a cultural community bounded by such factors as language, character, territory, political influence and formative influence (socialization of individuals within a certain tradition)..$^{16}$

Which one these definitions was used by Marcel de Serres? This question is not easy to answer, as he did not clarify that question explicitly. Obviously, he could not use the second one, as the Slavs in Europe were dispersed among many political or-

14 The Encyclopedia of Diderot \& d'Alembert Collaborative Translation Project, http://hdl. handle.net/2027/spo.did2222.0000.095 [date of entry: 6 V 2021].

15 Ibidem.

16 A. Patten, 'The Most Natural State': Herder and Nationalism, History of Political Thought 31 (2020) 4, pp. 667-668. 
ganisms and the author of Voyage en Autriche underlined many times that most of them are being ruled or even are succumbed to some sort of semi-voluntary slavery (an issue which will be discussed further). Hence, it was sure that they do not form any political entity bounded by a social contract. Most probably the understanding of that notion by de Serres lied close to the third mentioned definition because very big emphasis was put on the issue of language. Moreover, he underlined, that Slavs are not a community which "inhabit a certain expanse of country; confined within certain limits, and which obeys the same government" - as Encyclopedia traditionally defined "nation"17 - but are dispersed among many countries and governed by many rulers.

The most striking proof of this "national unity" of the Slavs consists of the comparison with the other groups labeled as nations. According to Marcel de Serres there were only few principal nations which inhabited the Habsburg Monarchy: Germans, Slavs, Wallachians and Hungarians. ${ }^{18}$ Hence, Poles, Czechs or Croats all were perceived as a part of one Slavic national community. Which factors led French author to such a conclusion? Firstly, it should be emphasized that the presumption that Slavs constitute some kind of entity was present in French literature already in the first half of $18^{\text {th }}$ century. In 1734 French historian J.G. Jolli in his history of the Kingdom of Poland stated that Slavs are one nation which "divided itself on as many names, as many provinces it occupied". ${ }^{19}$ De Serres followed that idea, and, as a proof that the internal denomination of the Slavs is only a derivative of geographic conditions, he pointed out that there are some Slavic communities that preserved their original name, i.e. Slovaks and Slovenes". ${ }^{20}$

The case of the Slovenes seems to deserve a broader analysis, as Marcel de Serres treated them as one of the most ancient Slavic peoples. He based his presumption on a traditional German denomination of Slavs (including Slovenes) as Venedi or Veneti, and an alternative geographical name of Carniola, i.e. Windismarck, the "March of

17 The Encyclopedia.

18 M. de Serres, Voyage en Autriche, vol. 1, p. 88.

19 “ (... ) cette Nation se partagea en. autant de noms différents qu'elle occupa de Provinces. Ceux qui s'établirent deçà \& delà le Danube prirent le nom de Serviens, Bulgares, Bosniens, Carniens, Rasciens, Dalmates, Esclavons, Illyriens, \& Istriens” - J.G. Jolli, Histoire Des Rois Et Du Royaume De Pologne, Et Du Grand Duche De Lituanie, La Haye 1734, vol. 1, pp. 4-5. 20 "Chacun de ces peuples a cependant reçu une dénomination particulière, qui n'est à proprement parler, qu'un nom géographique. Les seuls qui se soient contentés de la dénomination générale de Slawes, sont les Slovaques du nord de la Hongrie, et les peuplades confinées entre le Danube, la Save et la Kulpa et ces dernières se nomment elles-mêmes Slowenzi” - M. de Serres, Voyage en Autriche, vol. 4., p. 327. 
the Vindes". ${ }^{21}$ According to Marcel des Serres Windes settled in Styria in the year 620, and they migrated there from Dalmatia and Slavonia. ${ }^{22}$ The author of Voyage en Autriche claimed that the name Windes originates from German word die Wende ${ }^{23}$ which designates the inhabitant of the coast, thus this name could be applied not only to the Slavs inhabiting the coast of the Adriatic Sea, but also the Baltic Sea (the Poles).$^{24}$ Interestingly, other Napoleonic agent, Aleksander Sapieha, made similar observations on the "maritime" etymology of the term "Morlachs" used to describe population of the inland Dalmatia. ${ }^{25}$

The year 620 which appears in Marcel de Serres deliberations refers to the Constantine's Porphyrogenitus information about the arrival of the Croats at the Adriatic Sea in the times of the emperor Heraclius. ${ }^{26}$ The use of the term Windes can also be treated as a reference to the association of the Wenden (and thus the Slavs) with Germanic Vandals, which appears already in a work of German historiographer Albert Kranz entitled Vandalia (published in 1517). ${ }^{27}$ This "Germanic" trail was later followed by Mavro Orbini, Ragusan monk who in his work Il regno degli Slavi published in 1601 claimed that the Slavs came to Dalmatia from Scandinavia, and they are descendants of Goths. ${ }^{28}$ Marcel de Serres did not recall any of these theories

21 J. Lidl, Accurate Landkarte die Königreiche ober- und nieder-Hungarn, Slavonien, Croatien, Dalmatien, Bosnien, Servien, Bulgarien und Romanien, das gross Fürstenthum Siebenbürgen, die Fürstenthümer Moldau, Wallachien, Bessarabien, die Oczakowisch und Crimische Tartarey, die Pohlnische provinz Podolien, wie auch ein Theil von Ukranien und übrige angränzende Ländere vorstellen, Wien 1740-1749; J. Kindermann, Charte von Kaernthen und Krain, nebst den Grafschaften Görz und Gradiska und dem Gebiethe von Triest, Wien 1803.

22 M. de Serres, Voyage en Autriche, vol. 4, p. 341.

23 This word means "turn" or "turning point" but it is possible that it was associated with "brink" or "the edge".

24 Ibidem, vol. 4, p. 370.

25 Term "Morlach" originates from Greek term Mavrovlachoi (the black Vlachs), but Italian naturalist Alberto Fortis associated first part of this name with Slavic word more - the sea. Following this idea Alexander Sapieha claimed, that this ethnonym can be literally understood as "Lachs" (Poles) living near the Sea, and that means that they are strongly related with Poles "Lachs" living on pole (Polish for "field") - A. Fortis, Viaggio in Dalmazia, vol. 1, Venezia 1774, p. 47; A. Sapieha, Podróże, p. 30.

26 J. Rapacka, Leksykon tradycji chorwackich, Warszawa 1997, p. 145-148.

27 A. Merrills, R. Miles, The Vandals, London 2010, p. 15.

28 M. Orbini, Il Regno de gli Slavi hoggi corrottamente detti Schiavoni, Pesaro 1601, p. 7; J. Rapacka, Leksykon, p. 71. 
explicitly, but clearly suggested that Slovenes are one of the first Slavic peoples which appear in the historical documents. This fitted well the theory that the fact that the ethnonym "Slovenes" is a reference to Slavdom is not accidental: it testified some sort of primal nature of those people, who could be treated as "the original Slavs" (presumably along with the Slovaks). This idea, which seems to only be sketched by Marcel de Serres was explicitly presented by Charles Nodier, a French man of letters and the chief editor of the Télégraphe Officiel, the official journal of Illyrian Provinces. In his opinion it was the language of Slovenes which could be treated as original and primal Slavic language, ${ }^{29}$ and this theory was borrowed from the Slovene intellectuals themselves (such as Valentin Vodnik), as Nodier knew some of them personally. ${ }^{30}$

The presumed homogeneity of the character and language of the Slavic peoples mentioned by many Western observers could lead to the simplifications and stereotypes which paved the way for emergence of more complex and permanent concepts which served to describe the civilizational geography of Europe: i.e., the ideas of the Eastern Europe and of the Balkans. ${ }^{31}$ Those concepts implicate a set of general and still persisting ideas, such as the notion of the backwardness and the notion of the ethnic complexity which could be perceived as chaos. ${ }^{32}$ The latter issue, i.e., the ethnic complexity discovered by Western observers on the European territories of the weakening Ottoman Empire was often interpreted in a pejorative way as a proof of backwardness of those societies, as they could not organize themselves in a modern way and create the states. A French diplomat and writer Claude-Charles de Peyssonnel who published an extensive study on Slavs in 1765 stated that they were a population of barbaric descent. According to his analysis they were deprived of some sort of distinct identity, as they all were a mixture of different barbaric tribes invading Europe through centuries e.g., the Croats originated from Avars and Chrobats. ${ }^{33}$ The analysis of Marcel de Serres seems to be more favorable: he still claimed that the

\footnotetext{
29 W. Sajkowski, French image of the inhabitants, p. 77.

30 R. Maixner, Charles Nodier.

31 L. Wolff, Inventing Eastern Europe, pp. 285-291.

32 M. Todorova, The Trap of Backwardness: Modernity, Temporality, and the Study of Eastern European Nationalism, Slavic Review 64 (2005) 1, pp. 140-164.

33 C.Ch. de Peyssonnel, Observations historiques et géographiques sur les peuples barbares qui ont habité les bords du Danube et du Pont-Euxin; suivies d'un Voyage fait à Magnésie, à Thyatire, à Sardes, \&c. Contenant une Relation de ce qu'il y a de plus curieux en Monuments Antiques, Inscriptions, Médailles, dont plusieurs n'étaient pas encore connus; \& précédées d'une Dissertation sur l'origine de la Langue Sclavone prétendue Illyrique, Paris 1765, p. XV.
} 
origins of the Slavs are "obscure" (which for Peyssonnel was a proof that they were barbarians unable to write down their own history ${ }^{34}$ ), yet he tried to present some more systematic image of various Slavic populations. ${ }^{35}$

\section{Inner divisions of the "Slavic nation" according to Marcel de Serres}

In the fourth volume of his travelogue Marcel de Serres presented a very detailed scheme of the inner divisions of the "Slavic nation". According to Marcel de Serres the Slavs of the Habsburg Monarchy formed two geographical branches (Western and oriental) and were divided into seven principal races, and twenty-seven "secondary branches": "Thus, in the Austrian Monarchy alone, there are up to seven main races of the Slavs, the Czechs, the Slovaks, the Hannaques, the Poles, Windes, Rascians and Croats". According to these diagrams the Oriental Slavs of Habsburg Monarchy consisted of Czechs, further divided into "Bohemians" and "Moravians", Slovaks "of Hungary, of the Troppau plain, and those of Moravia", Poles which were further divided on Ruthenians (Russniaques ${ }^{36}$ ) and proper Poles. The last race of the Occidental Slavs inhabiting the Habsburg Monarchy were Hannaques (Slavs of the Haná region in Moravia), also internally sub-divided into few secondary branches (Hannaques, Blatniaques, Sabetschakes, Lippowanes). Of course, this "Western branch" was larger and included also the Slavs who lived outside the Habsburg Monarchy (e.g., Sorbs of Lusatia or Kashubians). The "oriental branch" of the Slavic nation of the Habsburg Empire included "Rascian" Slavs, or "Illyrian" race. It consisted of Croats, Slovenes (Windes) and Serbs, who incorporated many other groups, including Montenegrins, inhabitants of Ragusa, "Slavic Vlachs", Istrians or Dalmatians. ${ }^{37}$

The systematization proposed by Marcel de Serres should be analyzed in the context of the anthropology of Enlightenment which classified human societies according to different criteria, e.g., the way they obtained food, or the manner of liv-

\footnotetext{
34 Ibidem, p. X.

35 M. de Serres, Voyage en Autriche, vol. 4, p. 333.

36 Marcel de Serres precises that the name of Russniaques denominates inhabitants of Pokucie, Red Ruthenia and Hutsuls.

37 Ibidem, vol. 4, p. 378.
} 
ing in general, but also their physical appearance. ${ }^{38}$ It was mainly the latter aspect which served as a basis for the new definition of the race, which was an alternative term for descendance or bloodline before. ${ }^{39}$ Since the beginning of the $19^{\text {th }}$ century French, German and British physical anthropologists started to associate the race mainly with the physical differences and initiated the research in craniometry. Notwithstanding that tendency, Marcel de Serres did not mention any physical differences between different races of the Slavs (e.g., between the Poles and Czechs). Surprisingly, in Voyage en Autriche Marcel de Serres referred to some anthropologists which led the foundations for scientific racism, e.g., to Georges Cuvier, ${ }^{40}$ who at the beginning of $19^{\text {th }}$ century expressed his belief that anatomical differences determined moral and intellectual condition of man. ${ }^{41}$ The scheme presented by Marcel de Serres included a variety of other criteria of inner differentiation of the Slavs, like language or main economic activities, such as farming or shepherding. Such perspective might seem inconsequent, but all those criteria might also be perceived as a derivative of one factor: natural conditions (i.e., geography and climate). Hence, Marcel de Serres understood the notion of the race similarly to the father of French anthropology, Georges-Louis Leclerc de Buffon, who treated it as a sort of human variety shaped by the natural environment. ${ }^{42}$

Already in Jolli's theory, that Slavs had taken various names form the name of the lands they occupied, ${ }^{43}$ the primacy of geography seems to be emphasized. From that idea a very singular conclusion could be drawn: all names of the Slavic population are in fact topoethnonyms. In Marcel de Serre's theory this influence of geography was much more profound as it involved the influence of the physiography, i.e., climate, or landform, but also many other factors. His theory which has a lot of in

38 M. Duchet, Anthropologie et histoire au siècle des Lumières, Paris 1971, p. 87-102; B. Douglas, Climate to Crania: science and the racialization of human difference, [in:] Foreign Bodies Oceania and the Science of Race 1750-1940, ed. by B. Douglas, Ch. Ballard, Canberra 2008, p. 36.

39 The earliest use of the term "race" dates back to the $16^{\text {th }}$ century, the term meaning family, relatives or offspring of a common ancestor, as in the phrase "race \& stocke of Abraham" B. Douglas, Climate to Crania, p. 34.

40 M. de Serres, Voyage en Autriche, vol. 1, p. 330.

41 B. Douglas, Climate to Crania, p. 33.

42 N. Hudson, From "Nation" to "Race": The Origin of Racial Classification in Eighteenth-Century Thought, Eighteenth-Century Studies 29 (1996) 3, p. 254.

J.G. Jolli, Histoire Des Rois. 
common with Montesquieu's climate determinism ${ }^{44}$ and Buffon's anthropology $y^{45}$ assumes that the Slavs were a population which was very susceptible to external influence. This is visible especially on the example of the Slavic language, which for Marcel de Serres was an entity flexibly shaped by external factors of various nature:

The Slavic language varies a lot in its pronunciation. This pronunciation is almost always relative to the character of peoples. In truth, we see that the nature of the place and the configuration of the soil where it was transplanted also had an influence. Thus, it is sharper and harsher among the mountain people, either because obliged to call each other from afar, they needed to raise their voices to be heard, or because the mountain peoples like to experience sensations. On the contrary, this same language is sweeter and more melodious among the Slavs, who live on fertile plains. It is above all in the mouth of a Carniolan that the Slavic seems to have harmony and seems capable of absorbing these varied intonations which make the charm of the Italian language. Nothing is so hard, on the contrary, as the guttural accent of the Slavs of Bohemia and Styria, especially those who inhabit the arid and mountainous regions of these provinces. ${ }^{46}$

Here, de Serres indicates at least two independent layers of influence. The first are the natural conditions, e.g., the mountains which made Slavic language "harsher", while lowlands made it more subtle. Perception of the natural conditions as a factor which could shape human bodies, characters and cultures (including languages) which is visible in the deliberation made by Marcel de Serres should not surprise. In his work he cited Georges-Louis Leclerc de Buffon, ${ }^{47}$ one of the most important

44 K. Kreisel, Montesquieu: Possibilistic Political Geographer, Annals of the Association of American Geographer 58 (1968) 3, pp. 557-574.

45 N. Hudson, From "Nation" to "Race", p. 254.

46 "La langue esclavonne varie beaucoup dans sa prononciation. Cette prononciation est presque toujours relative au caractère des peuples. A la vérité, on voit que la nature des lieux et la configuration du sol où elle s'est trouvée transplantée y ont eu également de l'influence. Ainsi, elle est plus aiguë et plus rude chez les montagnards, soit qu'obligés de s'appeler de loin, ils aient eu besoin d'élever la voix pour se faire entendre, soit que les peuples des montagnes aiment à éprouver des sensations plus fortes. Cette même langue est, au contraire, plus douce et plus mélodieuse chez les Slawes qui habitent des plaines riantes et fertiles: c'est surtout dans la bouche d'une Carniolienne que l'esclavon parait avoir de l'harmonie, et semble susceptible de recevoir ces intonations variées qui font le charme de la langue italienne. Rien n'est si dur, au contraire, que l'accent guttural des Esclavons de la Bohême et de la Styrie, surtout de ceux qui habitent les contrées arides et montagneuses de ces provinces" - M. de Serres, Voyage en Autriche, vol. 4, p. 324.

47 Ibidem, p. 330. 
French naturalists and anthropologists of the Enlightenment period who perceived climate and diet as main factors shaping the character of different populations.$^{48} \mathrm{De}$ Serres was also a naturalist himself and later made important discoveries in the domain of the human prehistory as a paleontologist. ${ }^{49}$ Interestingly, also other discoverers of Slavic culture from late $18^{\text {th }}$ and the beginning of $19^{\text {th }}$ century like Alberto Fortis or Balthasar Hacquet were the naturalists who perceived human societies in the context of natural conditions in which they lived. ${ }^{50}$

The second layer of influence was the cultural impact of the neighboring nations: Slavic language could easily be Italianized or Germanized. Speaking about Marcel de Serres' perception of the Slavic language it should be emphasized that its internal flexibility and widespread character was perceived very positively, as a proof of its primordiality and close relation to nature. This fact shows the shift which occurred in French perception of Slavdom from the second half of $18^{\text {th }}$ century. In 1765 Claude-Charles de Peyssonnel was claiming, that the commonness of the Slavic language is a proof of its vulgarity, and primitiveness which made it improper for higher culture (which was a heritage of the barbarian hostility towards a cultural legacy of the Roman Empire). ${ }^{51}$ According to Claude-Charles de Peyssonnel, the Slavic language was in antiquity the lingua franca of the barbarians, allowing very different tribes Scythians could communicate with each other. Marcel de Serres very strongly criticized similar opinions and to contradict such opinions he cited Italian transcription of the Slavic poem from Carniola, showing that this language was proper for art. ${ }^{52}$

48 M. Duchet, Anthropologie et histoire..., p. 203.

49 P.O. Antoine, B. Meyer-Berthaud, T. Danelian, B. Lefebvre, T. Servais, Paleontology in France: 200 years in the footsteps of Cuvier and Lamarck, Palaeontologia Electronica 15 (2012) 1, https://palaeo-electronica.org/content/2012-issue-1-articles-2/79-palaeontology-in-france [date of entry: 1 V 2021].

50 M. Knezović, Morlak kao prirodni čovjek u djelima Alberta Fortisa, Ivana Lovrića i Balthasara Hacqueta, [in:] Triplex Confinium (1500.-1800.). Ekohistorija - Zbornik radova, Književni krug Split, Zavod za hrvatsku povijest Filozofskog fakulteta Sveučilišta u Zagrebu, ed. by E. Ivetić, D. Roksandić, Split-Zagreb 2003, p. 125-141; Ch. Gauchon, A. Kranjc, Balthasar Hacquet, pionnier de la karstologie, Karstologia 61 (2013), pp. 45-52; L. Wolff, Venice and the Slavs: The Discovery of Dalmatia in the Age of Enlightenment, Stanford 2001, pp. 77-78.

51 C.Ch. de Peyssonnel, Observations historiques, p. XXXIX.

52 M. de Serres, Voyage en Autriche, vol. 4, p. 330. 
According to Marcel de Serres the Slavic character was - just like the language - very susceptible to influence. Depicting the history of Czechs, he underlined that a strong leadership could tame warlike and barbaric nature of the Slavs: "One can look at Przemysl as the first ruler of Bohemia. His first care was to soften the coarse spirit and rebellious temper of the Bohemians. Little by little he accustomed them to obedience and gave them laws as wise as they were just". ${ }^{53}$ The fact that Slavs were so susceptible to the external influence was -according to Marcel de Serres - the reason behind their inferior social position (serfdom) despite their demographic predominance which resulted from fertility of Slavic women. ${ }^{54}$ According to author of Voyage en Autirche the situation of the Slavs would be much better if they would all live in one country and were obedient to the same laws, also because they preserved some kind of the uniformity of character..$^{55}$ Interestingly, his reflection coincided with the creation of Illyrian Provinces, which were presented by French propaganda as "liberation" of the South Slavs by Napoleon. ${ }^{56}$

In 1774 Italian naturalist Alberto Fortis published the first translation of South Slavic traditional epic poems. This fact, as well as Rousseau's appraisal of the uncorrupted nature of the societies living on the peripheries of civilized word (which developed already existing myth of noble savage ${ }^{57}$ ) and emergence of sentimentalist literature completely changed the way the Slavs of Dalmatia started being perceived. After the episode of the French rule in the Balkans (1806-1813) the interest in the Slavic matters was growing thanks to such authors as Charles Nodier or Prosper le Merimée. ${ }^{58}$ The analysis of Marcel de Serres anticipates this fascination with Slavic folklore which has grown in times of Romanticism by focusing on those aspects of matter which seemed to be most exotic and curious. Perhaps that was the reason behind mentioning Hannaques as one of the seven principal races of the Slavs inhabiting the Habsburg Monarchy. One of their sub-races were Lippowans (Lipovans) of Bukovina which might seem confusing as term Hannaques was describing Slavs from Moravian Haná region. The extensive description of this branch of the Slavs

53 "On peut regarder Przemysl comme le premier souverain de la Bohême. Son premier soin fut d'adoucir l'esprit grossier et l'humeur rebelle des Bohêmes. Il les accoutuma peu à peu à l'obéissance, et leur donna des lois aussi sages que justes" - ibidem, vol. 3, p. 8.

54 Ibidem, vol. 4, pp. 328-329.

55 Ibidem, vol. 4, p. 327.

56 W. Sajkowski, French image of the inhabitants, p. 72.

57 M. Duchet, Anthropologie et histoire..., pp. 280-281.

58 I. Bešker, Morlacchi nella letteratura. 
shows that topography was not so important as specific manner of living characteristic for Vlachs (which term could be a socionym referring to shepherds or nomads in general):

The Lipovans of Bukovina never live anywhere except in the midst of forests, and, like the Slovaks of the same province, they recall, by the simplicity of their customs, the ancient patriarchs (...). Discussions of interest and dissension between families do not exist for them. Only occupied with the care of their flocks, they almost all lead a nomadic life (...). It often happens that they even leave Austria to pass into Moldavia, for all countries are indifferent to a pastoral people, and their homeland is to be found wherever nature provides for the slight needs of their existence. ${ }^{59}$

Depictions of the Slavic shepherds, such as Morlachs, which were discovered by Alberto Fortis, were one of the first portrayals of the Slavs as the European savages. ${ }^{60}$ Marcel de Serres adds to this example other Slavic populations which led semi-nomadic life and often lived on mountainous borderland areas only partially controlled by the states. The citation presented above shows that the Slavs which exercised transhumance shepherding (and were most commonly labeled as Vlachs) were far more interesting for external observer than this part of population which exercised the main Slavic economic activity: i.e., agriculture. ${ }^{61}$ The organization of the Vlach societies in katuns ${ }^{62}$ - sort of patriarchal corporations united by the bonds of blood - was perceived as archaic and primordial. Moreover, according to Jean Jacques Rousseau the main reason behind the inequality of men (and all its negative consequences like wars) was caused by the invention of property of the land, which

59 “Les Lippowanes de la Bukowine n' habitent jamais qu'au milieu des forêts, et comme les Slowaques de la même province, ils rappellent, par la simplicité de leurs meurs, les anciens patriarches $[\ldots]$. Les discussions d'intérêt et les dissensions entre les familles n'existent pas pour eux. Uniquement occupés du soin de leurs troupeaux, ils mènent presque tous une vie nomade [...]. Il leur arrive même souvent de quitter l'Autriche pour passer dans la Moldavie, car tous les pays sont indifférents à un peuple pasteur, et sa patrie se trouve partout où la nature fournit aux légers besoins de son existence - M. de Serres, Voyage en Autriche, vol. 4, p. 323.

60 L. Wolff, Venice and the Slavs, p. 333.

61 On relations between Slavs (farmers) and Vlachs (shepherds) see: I. Czamańska, Vlachs and Slavs in the Middle Ages and Modern Era, Res Historica 41 (2016).

62 M. Luković, Sezonowe migracje pasterzy na Batkanach: charakter, historia, transformacje, Res Historica 40 (2015), p. 71. 
did not exist among the semi-nomadic shepherd communities. ${ }^{63}$ That is why some of the observers, like Marcel de Serres, regarded Slavic Vlachs as the humanity in its most natural and most happy state.

\section{Conclusions}

To conclude, it should be emphasized that the study made by Marcel de Serres is a very representative example of the evolution of the Western European image of the Slavs at the brink of $18^{\text {th }}$ and $19^{\text {th }}$ centuries. The reflection on the Slavdom presented in Voyage en Autriche seems to be particularly interesting in the context of the emergence of the ideas of Eastern Europe and of the Balkans, as well as the Romantic fascination with the Slavic folk culture. Voyage en Autriche presents also some kind of transitional perspective as it tries to incorporate new terminology of the description of human populations discovered by the anthropology of the Enlightenment in time when the meaning of some of those terms (like that of "the race" or "the nation") was still vague.

The imaging of the Slavs of the Habsburg Monarchy made by Marcel de Serres seems to include two opposite tendencies. The first one consisted of an attempt of treating the Slavs as one entity, which was a continuation of the already existing perspective. However, in Voyage en Autriche this entity was labeled as "nation" which made this assumption even stronger. The second tendency consisted of a constant accumulation of the knowledge on the various Slavic populations and their languages and observation of the differences between them. Hence, the work of Marcel de Serres represents a very particular perspective in time in which the recognition of the different Slavic nations was still not obvious. Interestingly, already in the years 1809 and 1810, when the author of Voyage en Autriche was visiting the Habsburg Monarchy, French Napoleonic propaganda started to address South Slavs as "the Illyrian Nation", which shows a rather fast dynamics of this process of the inner differentiation of the Slavs.

\section{Bibliography}

Antoine P.O., Meyer-Berthaud B., Danelian T., Lefebvre B., Servais T., Paleontology in France: 200 years in the footsteps of Cuvier and Lamarck, Palaeontologia

63 M. Duchet, Anthropologie et histoire, pp. 271-280. 
Electronica 15 (2012) 1, https://palaeo-electronica.org/content/2012-issue1-articles-2/79-palaeontology-in-france [date of entry: $1 \mathrm{~V} 2021$ ].

Bešker I., Morlacchi nella letteratura europea, Roma 2007.

Czamańska I., Vlachs and Slavs in the Middle Ages and Modern Era, Res Historica 41 (2016), pp. 11-24.

Douglas B., Climate to Crania: science and the racialization of human difference, [in:] Foreign Bodies Oceania and the Science of Race 1750-1940, ed by B. Douglas, Ch. Ballard, Canberra 2008, pp. 33-97.

Duchet M., Anthropologie et histoire au siècle des Lumières, Paris 1971.

Fine J., When ethnicity did not matter in the Balkans: A Study of identity in pre-nationalist Croatia, Dalmatia and Slavonia in the medieval and early-modern periods, Ann Arbor 2006.

Fortis A., Viaggio in Dalmazia, Venezia 1774.

Gauchon Ch., Kranjc A., Balthasar Hacquet, pionnier de la karstologie, Karstologia 61 (2013), pp. 45-52.

Hazard P., La crise de la conscience européenne, Paris 1995.

Hudson N., From "Nation" to "Race": The Origin of Racial Classification in EighteenthCentury Thought, Eighteenth-Century Studies 29 (1996) 3, pp. 247-264.

Jolli J.G., Histoire Des Rois Et Du Royaume De Pologne, Et Du Grand Duche De Lituanie, La Haye 1734.

Kindermann J., Charte von Kaernthen und Krain, nebst den Grafschaften Görz und Gradiska und dem Gebiethe von Triest, Wien 1803.

Knezović M., Morlak kao prirodni čovjek u djelima Alberta Fortisa, Ivana Lovrića i Balthasara Hacqueta, [in:] Triplex Confinium (1500.-1800.). Ekohistorija - Zbornik radova, Književni krug Split, Zavod za hrvatsku povijest Filozofskog fakulteta Sveučilišta u Zagrebu, ed. by E. Ivetić, D. Roksandić, Split-Zagreb 2003, pp. 125-141.

Kohn H., Pan-Slavism: Its History and Ideology, New York 1960.

Kreisel K., Montesquieu: Possibilistic Political Geographer, Annals of the Association of American Geographer 58/3 (1968), pp. 557-574.

Langendorf J.J., Les voyageurs de l'Empire: l'Autriche-Hongrie à la découverte du monde, 1318-1918, Paris 1966.

Lidl J., Accurate Landkarte die Königreiche ober- und nieder-Hungarn, Slavonien, Croatien, Dalmatien, Bosnien, Servien, Bulgarien und Romanien, das gross Fürstenthum Siebenbürgen, die Fürstenthümer Moldau, Wallachien, Bessarabien, die Oczakowisch und Crimische Tartarey, die Pohlnische provinz Podolien, wie auch ein Theil von Ukranien und übrige angränzende Ländere vorstellen, Wien 1740-1749.

Luković M., Sezonowe migracje pasterzy na Bałkanach: charakter, historia, transformacje, Res Historica 40 (2015), pp. 61-95. 
Maixner R., Charles Nodier en Illyrie, Revue des études slaves 3/4 (1924), pp. 252-263. Matutinović L., Ogled o Ilirskim provincijama i Crnoj Gori, transl. J. Milinković, Zagreb 2009.

Merrills Andrew, Miles Richard, The Vandals, London 2010.

Orbini Mavro, Il Regno de gli Slavi hoggi corrottamente detti Schiavoni, Pesaro 1601.

Patten Alan, 'The Most Natural State': Herder and Nationalism, History of Political Thought 31 (2020) 4, pp. 657-689.

Peyssonnel C.Ch. de, Observations historiques et géographiques sur les peuples barbares qui ont habité les bords du Danube et du Pont-Euxin; suivies d'un Voyage fait à Magnésie, à Thyatire, à Sardes, \&'c. Contenant une Relation de ce qu'il y a de plus curieux en Monuments Antiques, Inscriptions, Médailles, dont plusieurs n'étaient pas encore connus; \& précédées d’une Dissertation sur l'origine de la Langue Sclavone prétendue Illyrique, Paris 1765.

Rapacka J., Leksykon tradycji chorwackich, Warszawa 1997.

Raspopović R., La France et la Russie dans les projets de redistribution du Sud-Est de l'Europe au début du XIXe siècle, [in:] Les Provinces illyriennes dans l'Europe napoléonienne, ed. J.O. Boudon, Paris 2015, pp. 77-85.

Sajkowski W., French image of the inhabitants of the Illyrian Provinces and the emergence of South Slavic nationalisms, Balcanica Posnaniensia. Acta et studia 27 (2020), pp. 69-80.

Sajkowski W., French image of the peoples inhabiting Illyrian Provinces, Warszawa-Bellerive-sur-Allier 2018.

Sapieha A., Podróże w krajach stowiańskich odbywane, red. T. Jabłoński, Novi Sad-Wrocław, 1983.

Serres M. de, Voyage en Autriche ou essai statistique et geographique sur cet empire (etc.), Paris 1814.

Šoja S., La saga napoléonienne en Bosnie au début du XIXe siècle, [in:] Les Provinces illyriennes dans l'Europe napoléonienne, éd. J.O. Boudon, Paris 2015, pp. 87-98.

The Encyclopedia of Diderot \& d'Alembert Collaborative Translation Project, http://hdl. handle.net/2027/spo.did2222.0000.095 [date of entry: 6 V 2021].

Todorova M., Imaging Balkans, Oxford 2009.

Todorova M., The Trap of Backwardness: Modernity, Temporality, and the Study of Eastern European Nationalism, Slavic Review, 64 (2005) 1, pp. 140-164.

Varlan O., La France, la Russie et les Balkans. Les plans de partage de l'empire ottoman (1808), [in:] Les Provinces illyriennes dans l'Europe napoléonienne, éd. J.O. Boudon, Paris 2015, pp. 29-42.

Withers Ch., Placing the Enlightenment: Thinking Geographically about the Age of Reason, Chicago 2007. 
Wolff L., Inventing Eastern Europe: the map of civilization on the mind of the Enlightenment, Stanford 1994.

Wolff L., Venice and the Slavs: The Discovery of Dalmatia in the Age of Enlightenment, Stanford 2001.

Yovanovitch V., La guzla de Prosper Mérimée, étude d’histoire romantique, Paris 1911.

\section{Summary \\ Image of the Slavs inhabiting the Habsburg Monarchy in Voyage en Autriche by Marcel de Serres}

This paper focuses on the depiction of the Slavs in a work by a French naturalist Marcel de Serres, published in 1814 and entitled Voyage en Autriche. This work is an example of the analysis including a very detailed reflection on Slavdom, made in time of the increasing political engagement of Napoleonic France in Southeastern and Central Europe. The author of the work deliberated on the character of the Slavs and their presumed national unity, simultaneously searching for the ways to explain very apparent differences between various Slavic populations. According to Marcel de Serres the Slavs of the Habsburg Monarchy formed two geographical branches (western and oriental) and were divided into seven principal races, and twenty-seven "secondary branches". Voyage en Autriche depicted regularities, which were supposed to characterize all of the Slavs, but Marcel de Serres devoted much attention to some details which were considered as exotic and later were described by the writers of the Romantic period fascinated with the Slavic culture.

The imaging of the Slavs of the Habsburg Monarchy made by Marcel de Serres seems to include two opposite tendencies. The first one consisted of an attempt of treating the Slavs as one entity, which was a continuation of the already existing perspective. However, in Voyage en Autriche this entity was labeled as "nation" which made this assumption even stronger. The second tendency consisted of a constant accumulation of the knowledge on the various Slavic populations and their languages and observation of the differences between them. Hence, the work of Marcel de Serres represents a very particular perspective in time in which the recognition of the different Slavic nations was still not obvious.

Wojciech Sajkowski

Nadesłany: 19 II 2021

Nadesłany po poprawkach recenzyjnych: 18 III 2021

Zaakceptowany: 23 V 2021 
Dr hab. Wojciech Sajkowski, prof. UAM

Uniwersytet im. Adama Mickiewicza w Poznaniu

Wydział Historii

ul. Uniwersytetu Poznańskiego 7

61-614 Poznań

e-mail: wojciech.sajkowski@amu.edu.pl 